\title{
Penerapan Sistem Fuzzy Logic pada Alat Ukur Kadar Nutrisi pada Sistem Hidroponik
}

\section{(Application of Fuzzy Logic System in Nutrition Level Measurement in Hydroponic Systems)}

\author{
Andi Azizah ${ }^{1 *}$, Abdul Waris ${ }^{2)}$, Muhammad Tahir Sapsal ${ }^{3)}$ \\ ${ }^{1)}$ Program Studi Keteknikan Pertanian Universitas Hasanuddin \\ 2) Program Studi Keteknikan Pertanian Universitas Hasanuddin \\ 3) Program Studi Keteknikan Pertanian Universitas Hasanuddin \\ "Email korespondensi: dediardianto26@gmail.com
}

\begin{abstract}
ABSTRAK
Sistem hidroponik merupakan cara produksi tanaman yang sangat efektif. Pada umumnya pemberian nutrisi pada sistem ini tidak menyesuaikan banyak sedikitnya nutrisi yang dibutuhkan dari masa penanaman hingga waktu pemanenan. Tujuan penelitian ini adalah untuk menghasilkan alat ukur nutrisi berbasis fuzzy logic yang dapat digunakan pada sistem hidroponik. Pembuatan program fuzzy logic terdiri dari fuzzifikasi, aplikasi fungsi implikasi dan komposisi aturan, serta defuzzifikasi. Berdasarkan hasil penelitian yang telah dilakukan dapat diketahui bahwa sensor memenuhi kriteria yaitu tanggapan waktunya cepat, relatif stabil, pengaruh suhu yang relatif kecil, sensitif, linear dengan nilai R2 $=0.996$, kesalahan pembacaan yang relatif kecil yaitu $7.75 \%$.
\end{abstract}

Kata Kunci: fuzzy logic, sensor, dan kadar nutrisi.

\section{PENDAHULUAN}

\section{Latar Belakang}

Sistem hidroponik merupakan cara produksi tanaman yang sangat efektif. Sistem ini dikembangkan berdasarkan alasan bahwa jika tanaman diberi kondisi pertumbuhan tanaman yang optimal, maka potensi maksimum untuk berproduksi dapat tercapai. Hal ini berhubungan dengan sistem perakaran tanaman, dimana pertumbuhan perakaran tanaman yang optimum akan menghasilkan pertumbuhan tunas atau bagian atas yang sangat tinggi. Pada sistem hidroponik, larutan nutrisi yang akan diberikan mengandung komposisi garam-garam organik yang berimbang untuk menumbuhkan perakaran dengan kondisi lingkungan perakaran yang ideal (Rosliani dan Sumarni, 2005).
Teknologi hidroponik ini memiliki banyak keunggulan dibandingkan dengan teknik bertanam secara tradisional. Keunggulan hidroponik antara lain ramah lingkungan, produk yang dihasilkan higienis, pertumbuhan tanaman lebih cepat, kualitas hasil tanaman dapat terjaga, dan kuantitas dapat lebih meningkat. Sayuran yang diproduksi dengan sistem hidroponik juga menjadi lebih sehat karena terbebas dari kontaminasi logam berat industri yang ada di dalam tanah, segar dan tahan lama serta mudah dicerna (Indriasti, 2013).

Pada umumnya pemberian nutrisi pada sistem hidroponik dilakukan dengan mencampurkan nutrisi pada air kemudian mengalirkannya dengan menggunakan pompa dan tidak menyesuaikan banyak sedikitnya nutrisi yang dibutuhkan dari masa penanaman hingga waktu pemanenan. 
Hal ini dikarenakan belum tersedia alat yang dapat mengukur kadar nutrisi secara terus menerus, presisi, stabil, dan memiliki range pengukuran yang lebar.

Berdasarkan uraian di atas, maka perlu dirancang alat ukur nutrisi hidroponik yang presisi serta dapat dikembangkan untuk data logger sehingga dapat diketahui kebutuhan nutrisi terbaik yang harus diterapkan pada sistem hidroponik. Untuk membangun alat ukur yang presisi, dapat dilakukan dengan perancangan sistem hardware kompleks atau penerapan software cerdas. Penerapan software cerdas dapat dilakukan dengan menerapkan sistem fuzzy logic pada alat ukur. Dengan demikian, alat tersebut dapat menjadi salah satu alternatif untuk mendesain sistem data logger yang akurat.

\section{Tujuan dan Kegunaan}

Tujuan penelitian ini adalah untuk menghasilkan alat ukur nutrisi berbasis fuzzy logic yang dapat digunakan pada sistem hidroponik.

Kegunaan dari penelitian ini adalah sebagai salah satu solusi untuk mengembangkan sistem hidroponik.

\section{METODE PENELITIAN}

\section{Waktu dan Tempat}

Penelitian ini dilaksanakan pada April 2017 sampai Juli 2017, bertempat di Laboratorium Instrumentasi dan Kontrol, Program Studi Keteknikan Pertanian, Jurusan Teknologi Pertanian, Universitas Hasanuddin, Makassar.

\section{Alat dan Bahan}

Alat yang digunakan pada penelitian ini adalah oscilloscope, stopwatch, thermometer digital, solder, obeng, timbangan dengan standar deviasi $0.001 \mathrm{~g}$, Codevision AVR, Microsoft Excel 2010, Matlab 2010, dan laptop AMD E1.

Bahan yang digunakan pada penelitian ini adalah larutan garam dengan berbagai tingkat ppm, timah, komponen elektronika, mikrokontroler AT Mega 32, dan LCD 2 x 16.

\section{Prosedur Penelitian}

Adapun prosedur penelitian ini terdiri dari 8 tahapan dan dapat dilihat pada diagram alir penelitian pada Gambar 13.

\section{Perancangan Sistem}

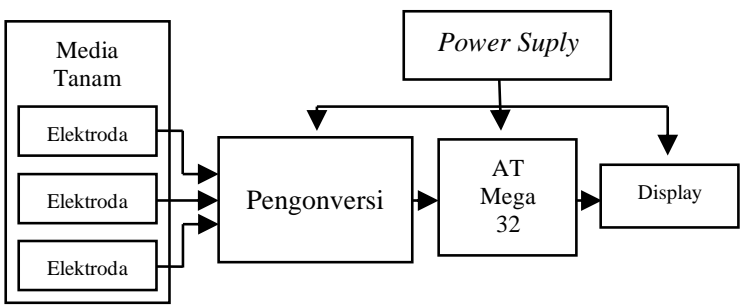

Gambar 1. Gambaran umum sistem

Sistem ini dirancang dengan syarat mampu mengukur nutrisi, menampilkan hasil ukur, mengumpulkan data, dan mentransfer data.

\section{Diagram Alir Penelitian}

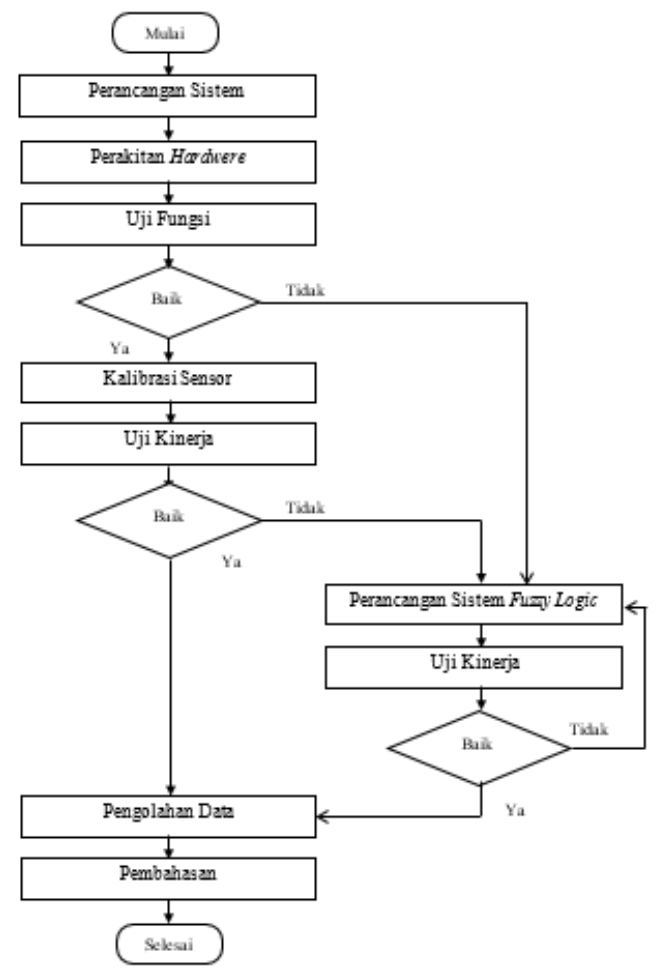

Gambar 2. Diagram Alir Penelitian

\section{Perakitan Perangkat Keras Catudaya}

Rangkaian catudaya yang digunakan pada penelitian ini adalah catudaya simetris yang menghasilkan tegangan sebesar $12 \mathrm{~V}$ yang berupa tegangan positif dan negatif. Tegangan keluar dari rangkaian ini digunakan untuk ketiga rangkaian sensor. 


\section{Alat Pengonversi}

Alat pengonversi terdiri dari tiga bagian, yaitu Oscilator, penguat tegangan, Digital to Analog Converter (DAC) dan Filter. Oscilator berfungsi untuk membangkitkan sinyal frekuensi menjadi $10 \mathrm{Khz}$ yang akan digunakan elektroda untuk menghatarkan arus listrik AC pada elektroda lainnya (electrical conductivity). Frekuensi ini bertujuan untuk menghindari gangguan dari frekuensi yang lebih tinggi maupun yang lebih lendah. Penguat tegangan berfungsi untuk menguatkan tegangan yang dihasilkan dari electrical conductivity. Tegangan yang dihasilkan berupa tegangan AC kemudian diubah menjadi tegangan DC oleh DAC. Setelah itu, tegangan disaring oleh filter sebelum masuk ke dalam mikrokontroler.

\section{Rangkaian Elektroda}

Elektroda yang digunakan adalah elektroda stainless yang dirakit membentuk batang sejajar dengan jarak $2 \mathrm{~cm}$. Elektroda kemudian dihubungkan dengan rangkaian sensor kadar nutrsi yang telah dirakit menggunakan kabel sensor sepanjang $2 \mathrm{~m}$.

\section{Perakitan Alat Ukur}

Pada tahapan ini, dilakukan penggabungan seluruh komponen penyususn sistem. Catudaya dihubungkan dengan rangkaian pengonversi, mikrokontroler, dan display. Tiga buah elektroda dihubungkan pada rangkaian pengonversi. Setelah itu rangkaian pengonversi kemudian akan dihubungkan ke mikrokontroler dan display.

\section{Uji Fungsi}

Uji fungsi bertujuan untuk mengetahui apakah sensor telah dapat mengonversi konsentrasi larutan (ppm) menjadi tegangan $(\mathrm{mV})$ secara linear. Adapun langkahlangkah dalam melakukan uji fungsi adalah:

1. Menyiapkan larutan garam dengan bergam tingkat ppm (0ppm, 500ppm, 1000ppm, 1500ppm, 2000ppm, 2500ppm, 3000ppm, 3500ppm, 4000ppm)
2. Memasukkan elektroda sensor pada larutan garam

3. Mengamati apakah sensor telah berhasil mengonversi ppm menjadi $\mathrm{mV}$

4. Mengamati apakah hasil pembacaan sensor linear

\section{Kalibrasi Sensor}

Kalibrasi sensor bertujuan untuk menyamakan nilai pembacaan sensor dengan nilai sebenarnya. Proses ini dapat dilakukan apabila hasil konversi sensor linear dan stabil.

\section{Uji Kinerja Sensor}

Uji kinerja bertujuan untuk mengetahui kinerja sensor berdasarkan syarat-syarat kualitas sensor. Adapun parameter pengamatan pada penelitian ini adalah linearitas, sensitivitas, tanggapan waktu, pengaruh suhu, stabilitas waktu, dan range pengukuran.

1. Linearitas

Uji linearitas sensor bertujuan untuk mengetahui seberapa besar pengaruh variabel input terhadap variabel output. Adapun langkah-langkah yang dilakukan untuk mengetahui linearitas sensor adalah sebagai berikut:

a. Menyiapkan larutan garam dengan beragam tingkat ppm (0ppm, 500ppm, $1000 \mathrm{ppm}, \quad 1500 \mathrm{ppm}, \quad 2000 \mathrm{ppm}$, 2500ppm, 3000ppm, 3500ppm, 4000ppm)

b. Memasukkan elektroda pada sampel secara bergantian

c. Mencatat data hubungan tegangan $(\mathrm{mV})$ dengan sampel (ppm)

2. Sensitivitas

Uji sensitivitas sensor bertujuan untuk mengetahui tingkat kepekaan sensor terhadap kuantitas yang diukur. Sensitivitas sensor dapat dihitung menggunakan Persamaan 2.

$$
\text { Sensitivitas }=\frac{\text { Konsentrasi }(\mathrm{ppm})}{\text { Tegangan }(\mathrm{mV})}
$$

\section{Tanggapan Waktu}

Uji tanggapan waktu sensor bertujuan untuk mengetahui kecepatan sensor dalam mengonversi ppm menjadi $\mathrm{mV}$. Adapun langkah-langkah yang dilakukan untuk 
mengetahui tanggapan waktu sensor adalah sebagai berikut:

a. Menyiapkan 1 sampel larutan garam. Semua jenis sampel bisa digunakan kecuali sampel 0ppm

b. Memasukkan elektroda ke dalam sampel bersamaan dengan menyalakan stopwatch

c. Mencatat waktu yang dibutuhkan sensor untuk membaca ppm larutan

4. Pengaruh Suhu

Pengujian ini bertujuan untuk mengetahui pengaruh suhu terhadap kinerja sensor. Adapun langkah-langkah yang dilakukan untuk pengujian ini adalah sebagai berikut:

a. Menyiapkan larutan garam dengan bergam tingkat ppm (0ppm, 500ppm, 1000ppm, 1500ppm, 2000ppm, 2500ppm, 3000ppm, 3500ppm, 4000ppm)

b. Mengukur suhu larutan garam menggunakan thermocouple

c. Mengukur tegangan (mV) yang dihasilkan semua sampel pada suhu $25^{\circ} \mathrm{C}$

d. Menaikkan suhu sampel dengan cara menjemur sampel 2-3 jam

e. Mengukur tegangan (mV) yang dihasilkan semua sampel pada suhu $30^{\circ} \mathrm{C}$.

5. Stabilitas Waktu

Pengujian ini bertujuan untuk memberikan gambaran output sensor selama proses pengukuran. Adapun langkah-langkah yang dilakukan untuk pengujian ini adalah sebagai berikut:

a. Menyiapkan 1 sampel laurtan garam. Semua sampel bisa digunakan kecuali sampel 0ppm

b. Memasukkan elektroda ke dalam sampel selama 1 jam

c. Mencatat hasil pembacaan sensor setiap 5 menit.

6. Lebar Range Pengukuran

Pengujian ini bertujuan untuk seberapa lebar range pengukuran sensor. Pengujian ini dilakukan dengan cara konsentrasi (ppm) semua sampel kemudian membandingkan hasil pembacaan sensor dengan nilai sampel sebenarnya.

\section{Perancangan Perangkat Lunak}

Perancangan perangkat lunak dilakukan dengan cara mensimulasikan hubungan input dan output sensor pada software matlab. Setelah diperoleh kaidah yang tepat untuk diterapkan pada sensor, maka aturan-aturan fuzzy dibuat pada Code Vision AVR dimana software ini menggunakan bahasa $C$. Setelah pembuatan program selesai, selanjutkan di compile dalam bentuk file.Hex kemudian di upload ke dalam memory flash mikrokokntroler. Adapun model inferensi yang diterapkan adalah sugeno orde 1 .

\section{HASIL DAN PEMBAHASAN}

\section{Pembuatan Sensor Kadar Nutrisi}

Berdasarkan hasil penelitian yang telah dilaksanakan maka diperoleh alat ukur kadar nutrisi seperti Gambar berikut:

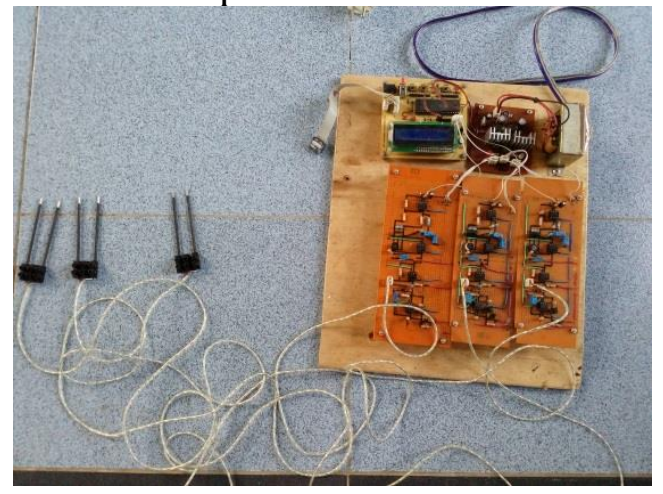

Gambar 3. Sensor Kadar Nutrisi

Alat tersebut telah mampu mengonversi konsentrasi larutan (ppm) menjadi tegangan $(\mathrm{mV})$. Prinsip kerja dari alat ukur ini adalah dengan membaca nilai electrical conductivity larutan kemudian mengubahnya menjadi tegangan, lalu tegangan tersebut dikonversi kembali menjadi ppm oleh mikrokontroler sebelum ditampilkan pada LCD. Semakin tinggi nilai ppm larutan, maka semakin tinggi tegangan yang dihasilkan.

\section{Uji Fungsi Sensor}

Setelah dilakukan uji fungsi sensor kadar nutrisi sesuai prosedur kerja, maka diketahui bahwa sistem sudah dapat mengonversi ppm menjadi $\mathrm{mV}$. Adapun 
hasil pengujian sensor berdasarkan 6 parameter antara lain adalah sebagai berikut:

\section{Linearitas}

Berdasarkan hasil uji linearitas sensor yang telah dilakukan maka diperoleh Gambar berikut:

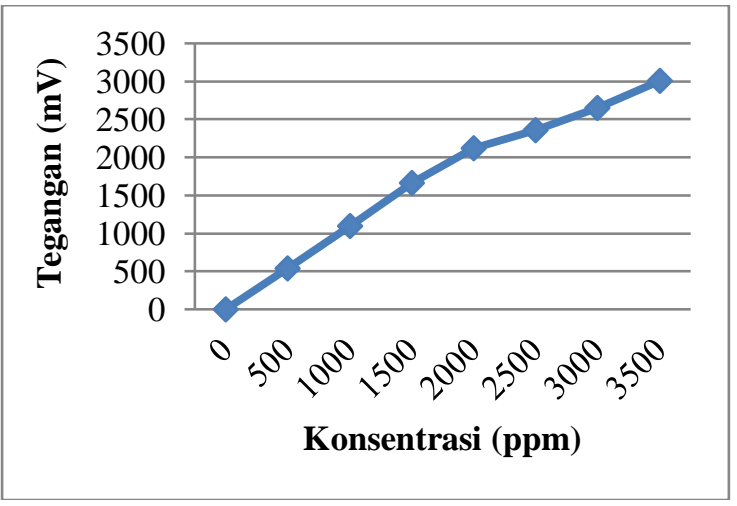

Gambar 4. Hasil uji linearitas sensor

Berdasarkan Gambar di atas dapat dilihat bahwa hasil konversi sensor tidak linear khusunya pada sampel 2500 ppm hingga 4000 ppm. Hal ini menandakan bahwa sensor tidak memenuhi syarat sensor yaitu linear.

\section{Tanggapan Waktu}

Berdasarkan hasil uji tanggapan waktu yang telah dilakukan maka diperoleh kecepatan konversi sensor adalah 1 detik. Hal tersebut menunjukkan bahwa sensor memenuhi tanggapan waktu. Hal ini sesuia dengan Widiyantoro (2013) bahwa salah satu syarat sensor adalah memiliki tanggapan waktu yang cepat.

\section{Stabilitas Waktu}

Berdasarkan hasil uji stabilitas waktu yang telah dilakukan maka diperoleh Gambar sebegai berikut:

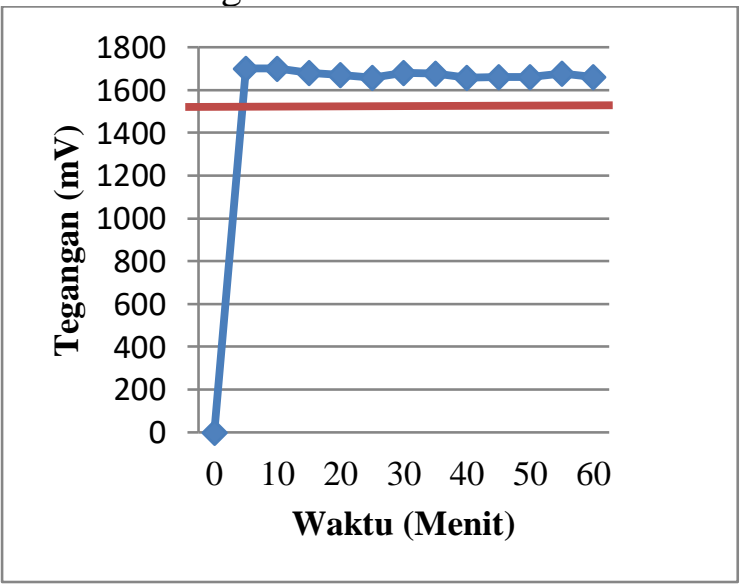

Gambar 5. Tanggapan waktu sensor kadar nutrisi

Berdasarkan gambar di atas dapat dilihat bahwa sensor memiliki stabilitas yang tinggi. Hal ini dibuktikan dengan tidak terjadi overshoot, offset yang rendah serta pembacaan yang cukup stabil. Hal ini sesuai dengan Widiyantoro (2013) bahwa salah satu syarat sensor adalah stabilitas waktu, yaitu untuk menilai masukan tertentu sensor harus dapat memberikan keluaran (output) yang nilainya tetap dalam waktu yang lama.

\section{Pengaruh Suhu}

Pada pengujian ini, suhu yang diterapkan adalah $25^{\circ} \mathrm{C}$ dan $30^{\circ} \mathrm{C}$. Berdasarkan hasil uji pengaruh suhu yang telah dilakukan maka diperoleh Grafik sebegai berikut:

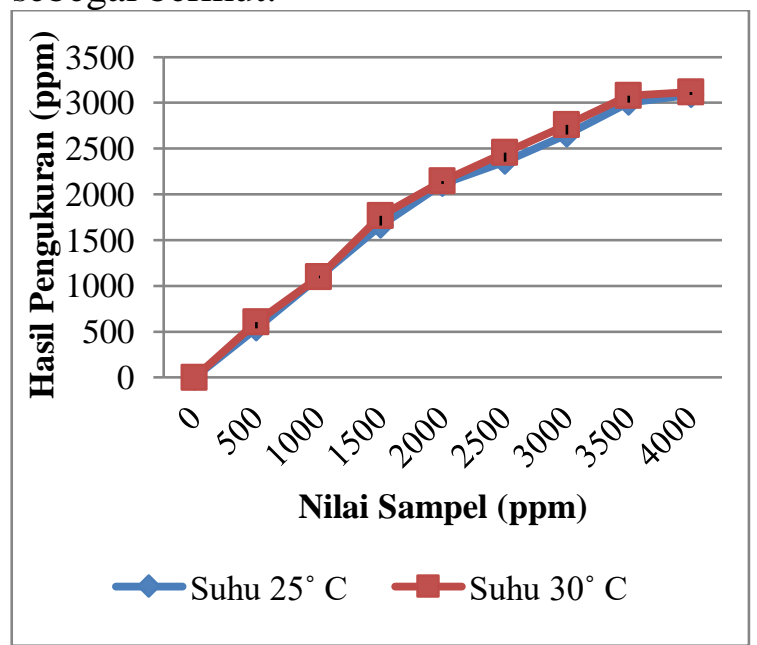

Gambar 6. Grafik pengaruh suhu pada sensor

Berdasarkan Grafik di atas dapat dilihat bahwa perubahan suhu menyebabkan kenaikan nilai pembacaan sensor akan tetapi pengaruhnya sangat kecil. Hal tersebut menunjukkan bahwa sensor telah memenuhi syarat sensor yaitu tidak tergantung temperatur. Hal ini sesuai dengan Widiyantoro (2013) bahwa salah satu syarat sensor adalah tidak dipengaruhi oleh suhu sekelililngnya, kecuali sensor suhu.

\section{Sensitivitas}

Berdasarkan hasil uji sensitivitas sensor yang telah dilakukan, maka diperolah Tabel sebagai berikut:

Tabel 1. Hasil Uji Sensitivitas Sensor 


\begin{tabular}{ccc}
\hline $\begin{array}{c}\text { Konsentrasi } \\
\text { Sampel (ppm) }\end{array}$ & $\begin{array}{c}\text { Tegangan } \\
(\mathbf{m V})\end{array}$ & $\begin{array}{c}\text { Sensitivitas } \\
(\mathbf{p p m} / \mathbf{m V})\end{array}$ \\
\hline 0 & 0 & 0 \\
500 & 538 & 0.93 \\
1000 & 1100 & 0.91 \\
1500 & 1662 & 0.90 \\
2000 & 2116 & 0.95 \\
2500 & 2361 & 1.06 \\
3000 & 2654 & 1.13 \\
3500 & 3006 & 1.16 \\
4000 & 3089 & 1.29 \\
\hline \multicolumn{2}{c}{ Rata-Rata } \\
\hline
\end{tabular}

Berdasarkan Tabel di atas, dapat dilihat nilai rata-rata sensitivitas sensor adalah $0.93 \mathrm{ppm} / \mathrm{mV}$ yang berarti setiap perubahan $0.93 \mathrm{ppm}$ pada masukan akan menghasilkan perubahan $1 \mathrm{mV}$ pada keluarannya. Hal tersebut menunjukkan bahwa sensor sangat sensitif dan memenuhi syarat sensor. Hal ini sesuai dengan Widiyantoro (2013) bahwa salah satu syarat sensor adalah sensor memiliki nilai sesitivitas sama dengan 1 .

\section{Range Pengukuran}

Berdasarkan hasil pengujian yang telah dilakukan maka dapat diketahui bahwa sensor memiliki range pengukuran $0 \mathrm{ppm}$ sampai 3089 ppm. Hasil tersebut dapat dilihat pada Tabel 2.

Tabel 2. Perbandingan Konsentrasi Larutan dengan Tegangan $(\mathrm{mV})$

\begin{tabular}{cc}
\hline $\begin{array}{c}\text { Konsentrasi larutan } \\
(\mathbf{p p m})\end{array}$ & Tegangan (mV) \\
\hline 0 & 0 \\
500 & 538 \\
1000 & 1100 \\
1500 & 1662 \\
2000 & 2116 \\
2500 & 2361 \\
3000 & 2654 \\
3500 & 3006 \\
4000 & 3089 \\
\hline
\end{tabular}

Berdasarkan Tabel di atas dapat dilihat bahwa hasil konversi sensor tidak linear khususnya pada konsentrasi 2500 ppm hingga 4000 ppm. Oleh karena itu, perlu dilakukan penerapan sistem fuzzy logic untuk melinearkan hasil konversi sensor.
Data tersebut selanjutnya digunakan sebagai dasar pembuatan kaidah-kaidah fuzzy.

\section{Perancangan Sistem Fuzzy Logic}

Perancangan sistem fuzzy logic terdiri dari 4 tahapan yaitu fuzzifikasi, aplikasi fungsi implikasi, komposisi aturan, dan defuzzifikasi. Pada penelitian ini digunakan sistem interferensi sugeno dengan member function segitiga.

\section{Fuzzifikasi}

Berikut ini adalah hasil dari proses fuzzifikasi dengan sembilan fungsi keanggotaan digunakan:

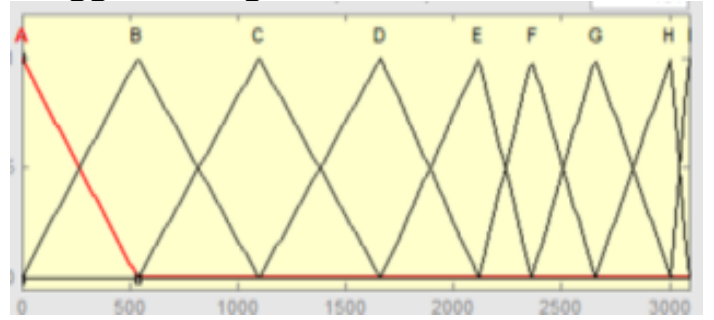

Gambar 7. Hasil pemetaan nilai input (tegangan) dengan kurva segitiga

Pada Gambar 7, menunjukkan hasil pemetaan titik-titik input ke dalam fungsi keanggotaan fuzzy menggunakan member function segitiga. Skala pada derajat keanggotaan adalah 0 sampai 1 , sementara skala pada semesta pembicaraan adalah 0 sampai 3089. Fungsi keanggotaan dibagi menjadi 9 himpunan fuzzy dengan label $\mathrm{A}$, B, C, D, E, F, G, H, dan I.

\section{Aplikasi Fungsi Implikasi dan Komposisi Aturan}

Berikut adalah hasil aplikasi fungsi implikasi dan komposisi aturan yang telah dilakukan:

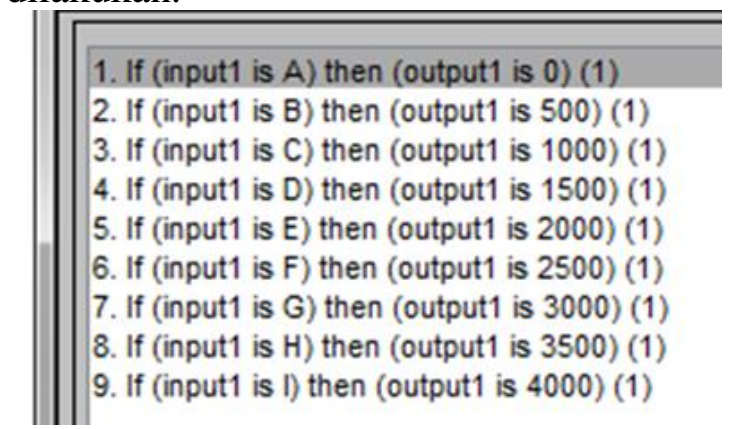

Gambar 8. Hasil proses basis aturan

Pada penelitian ini menggunakan satu masukan dan satu keluaran yang masing-masing terdiri dari 9 himpunan fuzzy. Berdasarkan hasil pembacaan awal 
sensor maka diperoleh hubungan antara nilai ppm sampel dengan tegangan $(\mathrm{mV})$, maka disusunlah beberapa aturan yang akan digunakan dalam perancangang software cerdas sensor. Semakin banyak aturan yang digunakan, maka semakin akurat hasil yang dikeluarkan sensor.

\section{Defuzzifikasi}

Berikut ini adalah hasil dari proses defuzzifikasi yang telah dilakukan:

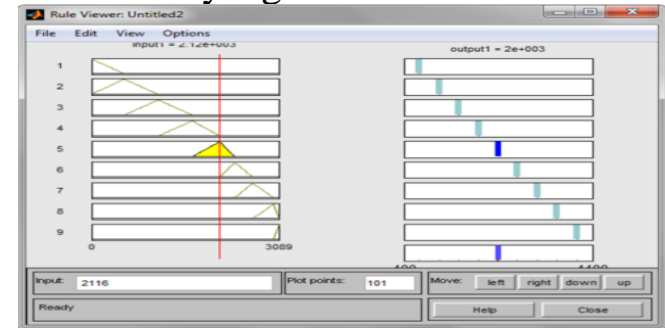

Gambar 9. Rule viewer fuzzy logic sensor kadar nutrisi

Gambar 9 merupakan hasil defuzzifikasi himpunan fuzzy (sebelah kiri) menjadi bilangan tunggal (sebelah kanan). Misalnya input sebesar $2116 \mathrm{mV}$ yang terletak diantara kurva 4, 5, dan 6 setelah melalui proses defuzzifikasi, diperoleh output senilai $2000 \mathrm{ppm}$. Hal ini juga menunjukkan bahwa fuzzy logic mampu meningkatkan linearitas hasil konversi sensor kadar nutrisi.

\section{Simulasi Pengukuran Nutrisi}

Berdasarkan hasil simulasi yang telah dilakukan, maka diperoleh data sebagai berikut:

Tabel 3. Hasil Simulasi Konversi Sensor

\begin{tabular}{cc}
\hline $\begin{array}{c}\text { Nilai Sampel } \\
\text { (ppm) }\end{array}$ & $\begin{array}{c}\text { Hasil Simulasi pada } \\
\text { Matlab (ppm) }\end{array}$ \\
\hline 0 & 0 \\
500 & 500 \\
1000 & 1000 \\
1500 & 1500 \\
2000 & 2000 \\
2500 & 2500 \\
3000 & 3000 \\
3500 & 3500 \\
4000 & 4000
\end{tabular}

Berdasarkan Tabel di atas dapat dilihat bahwa hasil simulasi pada matlab menunjukkan nilai yang sama dengan nilai yang sampel. Hal tersebut menunjukkan bahwa sistem fuzzy logic mampu melinearkan hasil konversi sensor. Kaidah-kaidah yang dibuat pada simulasi ini selanjutnya menjadi dasar pembuatan program fuzzy logic pada software Code Vision AVR untuk diterapkan pada sensor.

\section{Uji Kinerja Sensor Setelah Penerapan Sistem Fuzzy Logic}

Setelah dilakukan uji kinerja sensor maka diperoleh beberapa gambaran kinerja sensor berdasarkan dua parameter yang dipengaruhi oleh sistem fuzzy logic yaitu linearitas dan range pengukuran.

\section{Linearitas}

Berdasarkan hasil uji linearitas sensor yang telah dilakukan maka diperoleh grafik pada Gambar 10. Grafik tersebut menggambarkan perbandingan hasil pembacaan sensor sebelum diterapkan sistem fuzzy logic dan setelah diterapkan sistem fuzzy logic.

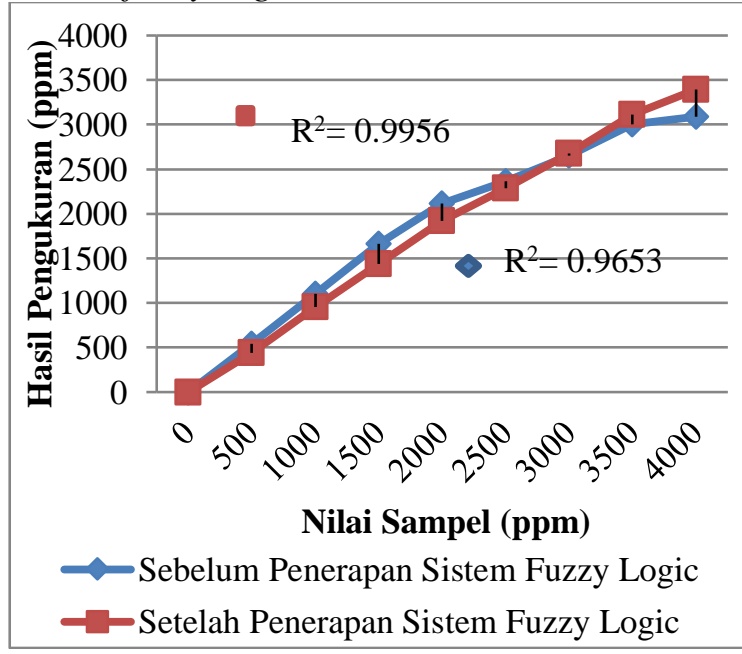

Gambar 10. Grafik pengukuran sensor

Berdasarkan Gambar 10 dapat dilihat bahwa nilai $\mathrm{R}^{2}$ pembacaan sensor mengalami peningkatan dari 0.9653 menjadi 0.9956 setelah diterapkan fuzzy logic. Hal ini menunjukkan bahwa linearitas sensor mengalami peningkatan yang berarti penerapan fuzzy logic pada sensor kadar nutrisi dapat meningkatkan ketelitian pembacaan sensor tersebut. Hal ini sesuai dengan Widiyantoro (2013) bahwa salah satu syarat sensor adalah linearitas tinggi yang berarti sensor menghasilkan sinyal keluaran yang berubah secara kontinyu sebagai tanggapan terhadap masukan yang berubah secara kontinyu. 
Range Pengukuran

Berdasarkan hasil pengujian yang telah dilakukan maka diperoleh data sebagai berikut:

Tabel 4. Hasil Pengukuran Lebar Range Sensor

\begin{tabular}{ccc}
\hline $\begin{array}{c}\text { Nilai } \\
\text { Sampel } \\
\text { (ppm) }\end{array}$ & $\begin{array}{c}\text { Hasil } \\
\text { Pengukuran } \\
\text { dengan sensor } \\
\text { (ppm) }\end{array}$ & $\begin{array}{c}\text { Hasil Pengukuran } \\
\text { Setelah Penerapan } \\
\text { Sistem Fuzzy Logic } \\
\text { (ppm) }\end{array}$ \\
\hline 0 & 0 & 0 \\
500 & 538 & 444 \\
1000 & 1100 & 952 \\
1500 & 1662 & 1439 \\
2000 & 2116 & 1918 \\
2500 & 2361 & 2288 \\
3000 & 2654 & 2673 \\
3500 & 3006 & 3112 \\
4000 & 3089 & 3394 \\
\hline
\end{tabular}

Berdasarkan tabel di atas dapat dilihat sistem fuzzy logic mampu meningkatkan lebar range sensor dari $0 \mathrm{mV}-3089 \mathrm{mV}$ menjadi $0 \mathrm{mV}$ - $3394 \mathrm{mV}$. Hal tersebut menunjukkan bahwa sensor belum mampu mencapai range $4000 \mathrm{mV}$. Hal ini dikarenakan faktor internal dan eksternal sensor yaitu kualitas komponen yang digunakan, noise pada sistem, serta lingkungan. Hal ini sesuai dengan Widiyantoro (2013) bahwa kinerja sensor dipengaruhi oleh lingkungan sekitarnya.

\section{Kesalahan Pembacaan}

Setelah seluruh pengujian telah selesai, maka dilakukan perhitungan nilai error untuk mengetahui kesalahan pembacaan sensor. Hasil tersebut dapat dilihat pada Tabel 5.

Tabel 5. Kesalahan Pembacaan Sensor

\begin{tabular}{|c|c|c|c|c|}
\hline \multicolumn{3}{|c|}{ Pengukuran Kadar Nutrisi } & \multicolumn{2}{|c|}{$\begin{array}{c}\text { Selisih Pembacaan } \\
\text { (Error) }(\%)\end{array}$} \\
\hline $\begin{array}{l}\text { Konsent } \\
\text { rasi } \\
\text { Sampel } \\
(\text { ppm) }\end{array}$ & $\begin{array}{c}\text { Sebelum } \\
\text { Diterapk } \\
\text { an Fuzzy } \\
\text { Logic } \\
(\mathrm{mV})\end{array}$ & $\begin{array}{c}\text { Setelah } \\
\text { Diterap } \\
\text { kan } \\
\text { Fuzzy } \\
\text { Logic } \\
\text { (mV) }\end{array}$ & $\begin{array}{c}\text { Sebelum } \\
\text { Diterap } \\
\text { kan } \\
\text { Fuzzy } \\
\text { Logic }\end{array}$ & $\begin{array}{c}\text { Setelah } \\
\text { Diterap } \\
\text { kan } \\
\text { Fuzzy } \\
\text { Logic }\end{array}$ \\
\hline 0 & 0 & 0 & 0 & 0 \\
\hline 500 & 538 & 444 & 7.60 & 11.20 \\
\hline 1000 & 1100 & 952 & 10.00 & 4.80 \\
\hline 1500 & 1662 & 1439 & 10.80 & 4.07 \\
\hline
\end{tabular}

\begin{tabular}{|c|c|c|c|c|}
\hline 2000 & 2116 & 1918 & 5.80 & 4.10 \\
\hline 2500 & 2361 & 2288 & 5.56 & 8.48 \\
\hline 3000 & 2654 & 2673 & 11.53 & 10.90 \\
\hline 3500 & 3006 & 3112 & 14.11 & 11.09 \\
\hline 4000 & 3089 & 3394 & 22.78 & 15.15 \\
\hline \multicolumn{3}{|c|}{ Rata-rata } & 9.80 & 7.75 \\
\hline
\end{tabular}

Berdasarkan hasil pengujian sensor pada tabel 5, dapat dilihat bahwa rerata nilai error pengukuran sensor menurun dari $9.80 \%$ menjadi $7.75 \%$ setelah diterapkan fuzzy logic. Hal ini menunjukkan bahwa pembacaan sensor setelah diterapkan fuzzy logic lebih akurat dibanding sebelum diterapkan fuzzy logic. Hal ini sesuai dengan Fulloy (1993), bahwa dalam pengukuran wilayah asal (domain), perkembangan ilmu komputer dan sains telah membawa kemajuan pada fungsi baru untuk sensor. Sensor baru ini disebut "smart sensor" (sensor cerdas).

\section{Uji Validasi Program}

Setelah dilakukan uji validasi program, maka diperoleh grafik perbandingan antara hasil simulasi matlab dengan hasil pengukuran sensor seperti gambar 20 .

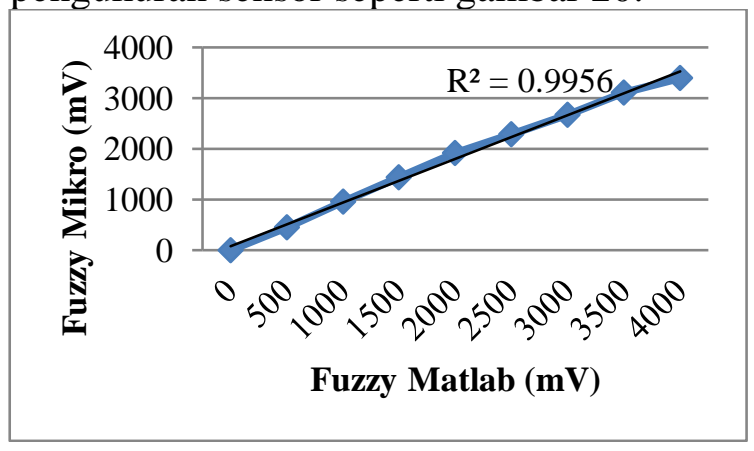

Gambar 11. Grafik perbandingan simulasi matlab dengan hasil konversi sensor.

Berdasarkan Gambar 11 dapat dilihat bahwa hasil pembacaan sensor sangat mendekati hasil simulasi pada matlab dengan nilai $\mathrm{R}^{2}=0.9956$. Hal ini menujukkan bahwa program yang diterapkan pada sensor valid. Hasil pembacaan sensor setelah diterapkan fuzzy logic dipengaruhi oleh hasil pembacaan awal sensor. Faktor yang memengaruhi perbedaan nilai pembacaan sensor dengan hasil simulasi adalah lingkungan. Pada simulasi matlab pengaruh lingkungan tidak diperhitungkan sementara pada pengukuran 
sebenarnya faktor lingkungan turut memengaruhi pembacaan sensor.

\section{KESIMPULAN}

Berdasarkan hasil penelitian yang telah dilakukan, diperoleh kesimpulan sebagai berikut:

1. Alat ukur kadar nutrisi telah berhasil dibuat dengan kinerja yang baik.

2. Alat ukur kadar nutrisi memiliki kinerja yang baik yaitu linear, tanggapan waktu cepat, relatif stabil, sensitif, pengaruh suhu relatif kecil.

\section{DAFTAR PUSTAKA}

Indriasti, Ratna. 2013. Analisis Usaha Sayuran Hidroponik pada PT Kebun Sayur Segar Kabupaten Bogor. Institut Pertanian Bogor: Bogor.

Rosliani, Rini dan Nani Sumarni. 2005. Budidaya Tanaman Sayuran dengan Sistem Hidroponik. Balai Penelitian Tanaman Sayuran: Bandung.

Widiyantoro, Huda. 2013. Media Pembelajaran Sensor dan Tranduser pada Program Studi Pendidikan Teknik Elektro Universitas Negeri Semarang. Universitas Negeri Semarang: Semarang. 